\title{
Participação no espaço público: o caso do Conselho das Cidades
}

Erica Maria Barroso Bernhardt

Curso: Mestrado em Sociologia

Data da defesa: 10 de agosto de 2009

Orientador: Prof. Dr. Eurico Antônio Gonzalez Cursino dos Santos

\section{Resumo}

Esta dissertação trata do processo de participação dos diferentes segmentos que fazem parte do Conselho das Cidades, vinculado ao Ministério das Cidades. Buscou-se saber em que medida a criação dessa instância participativa representou, de fato, uma mudança na forma como a política urbana nacional é desenvolvida e implementada. O processo de participação foi analisado considerando-se as experiências de diversos conselheiros, enfatizando de que formas as decisões são tomadas. O Conselho faz parte de uma tentativa de aprofundar a prática democrática e incluir novos atores na discussão sobre políticas urbanas, tendo como premissa que a participação é uma força democratizante e complementar à democracia representativa.

Os resultados mostram que houve limitações nesse processo de participação, pois houve a inserção de atores que, sem outros meios de influenciar essas políticas, não conseguem modificar o status quo. Entre os motivos estão: a discrepância entre a capacitação dos conselheiros, que criou condições desiguais no processo de deliberação e permitiu o uso do discurso técnico e jurídico para fins políticos; a forma como são desenvolvidas as discussões premia práticas que não levam em conta a publicidade e transparência do processo, sendo utilizados, principalmente, espaços 
informais para definir as posições finais do Conselho; o caráter consultivo do Conselho, fazendo com que suas resoluções não sejam necessariamente implementadas.

Apesar das limitações do Conselho, criou-se um espaço onde ocorrem debates que modificam o entendimento e os posicionamentos dos seus participantes. Portanto, é um espaço onde identidades políticas são construídas coletivamente e faz parte de um contexto político que busca a maior democratização das instituições com a adoção de práticas participativas.

Palavras-chave: participação; consenso; espaço público; democracia participativa; Conselho das Cidades. 